\title{
Electrophoretic pattern of plasma proteins in clinically diagnosed cases of kwashiorkor (protein malnutrition) and undernutrition (marasmus) among Ceylonese children
}

\author{
By N. G. BAPTIST, C. C. DE SILVA AND M. A. SIDEEK \\ Departments of Biochemistry and Pediatrics, Faculty of Medicine, \\ University of Ceylon, Colombo \\ (Received 30 April r959-Revised 27 Fuly 1959)
}

In spite of the numerous surveys (Brock \& Autret, 1952; Autret \& Behar, 1954; Waterlow \& Vergara, 1956) and studies (Gómez, Ramos-Galván, Cravioto, Frenk, De La Peña, Moreno \& Villa, I957; Politzer \& Wayburne, I957; Dean \& Schwartz, 1953; Scrimshaw, Behar, Arroyave, Viteri \& Tejada, 1956; Mukherjee \& Jeliffe, I955-6; Netrasiri \& Netrasiri, I955-6; Gopalan, 1955-6; Suckling \& Campbell, I957) conducted on the clinical, pathological and biochemical characteristics of kwashiorkor, no satisfactory criteria have emerged on which an unequivocal diagnosis of this condition can be made.

The chief purpose of the work reported here has been to try to find some relationship between the clinical signs of kwashiorkor (protein malnutrition) and undernutrition (marasmus), such as oedema, skin and hair changes, diarrhoea and fatty liver, and changes in plasma proteins. It occurred to us that if, having made a selection of cases of kwashiorkor on the one hand and cases of undernutrition on the other on the basis of clinical signs, we could make a clinical and biochemical study and establish certain criteria in cases of each type, it might be possible to arrive at a combination of clinical signs and biochemical criteria that would establish kwashiorkor and undernutrition as two distinct syndromes. With this end in view, two groups of patients, adjudged clinically to be suffering from kwashiorkor or undernutrition, were kept under close clinical and dietetic supervision while electrophoretic fractionation of plasma proteins and determinations of total plasma proteins were carried out.

EXPERIMENTAL

\section{Determination of total plasma proteins and individual protein fractions}

The determinations were made on all patients for 5 weeks or more from the time of admission except on two patients with undernutrition, one of whom $\left(\mathrm{U}_{3}\right)$ was diagnosed after 3 weeks as a case of pyelonephritis and the other $\left(U_{6}\right)$ died 2 I days after admission to hospital.

Heparinized blood was obtained once a week by venepuncture, placed in dry tubes, and centrifuged. The plasma was then used for: (I) total-protein estimation, on $0.2 \mathrm{ml}$, by the method described by King (I95 I); and (2) electrophoretic estimation of individual protein fractions (Grassmann, 195I). An EEL (Evans Electroselenium 
Ltd) paper-electrophoresis apparatus was used with veronal buffer of $\mathrm{pH} 8.6$ and ionic strength 0.05 .

Serum $(0.025 \mathrm{ml})$ was streaked across a $5 \mathrm{~cm}$ wide strip of Whatman no. I filterpaper and electrophoresis was carried out with a current of $0.4 \mathrm{~mA} / \mathrm{cm}$ width of paper for $\mathrm{I} 7 \mathrm{~h}$ (usually overnight). At the end of this time the paper was dried in an oven at $120^{\circ}$ for $20-30 \mathrm{~min}$ and stained with a saturated solution of amidoschwarz $10 B$ in acetic acid and methanol $(\mathrm{r}: 9, \mathrm{v} / \mathrm{v})$. After the excess dye had been rinsed out with the same solvent, the paper was dried in the oven, rendered translucent with paraffin under reduced pressure, and finally mounted in the EEL scanner for quantitative estimation of the individual bands.

Early in the investigation it was found that paper soaked in I \% aqueous sodium citrate gave an improved separation of the individual fractions, and this technique was subsequently used.

\section{Subjects}

The subjects were selected from hospital cases under the care of one of us (C. C. de S.) at the Lady Ridgeway (Children's) Hospital, Colombo. Their previous history was obtained by questioning the parents.

Kwashiorkor. This condition is defined as one showing at some time or other some of the following signs and symptoms: underweight or underdevelopment or both, varying degrees of oedema, muscular atrophy, emotional changes such as irritability or apathy, anorexia, fatty liver which may or may not be clinically palpable, anaemia, diarrhoea, skin and hair changes.

Seven cases, three males and four females (Table I), showing some or all of these signs were selected for study in this group; except for one case all were from rural or semi-urban areas. Their ages ranged from 7 months to 3 years and 8 months.

Undernutrition (marasmus). This condition is defined in this context as an atrophic state characterized by a severe degree of wasting. Skin changes (usually found in

Table I. Sex, age and weight on admission of patients with kwashiorkor or undernutrition

\begin{tabular}{|c|c|c|c|c|c|}
\hline \multirow{2}{*}{$\begin{array}{l}\text { Patient, } \\
\text { code no. }\end{array}$} & & \multicolumn{2}{|c|}{ Age } & \multicolumn{2}{|c|}{ Weight } \\
\hline & Sex & Years & Months & lb & $\mathbf{o z}$ \\
\hline \multicolumn{6}{|c|}{ Kwashiorkor group } \\
\hline $\mathrm{K}_{1}$ & q & 2 & 2 & 15 & 13 \\
\hline $\mathrm{K}_{2}$ & 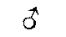 & 2 & 6 & 15 & I5 \\
\hline$K_{3}$ & 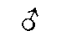 & $\mathbf{I}$ & 4 & 16 & IO \\
\hline $\mathrm{K}_{4}$ & 우 & 3 & 8 & 17 & 6 \\
\hline $\mathrm{K}_{5}$ & 웅 & 0 & 8 & 8 & 12 \\
\hline$K_{6}$ & 오 & $\circ$ & 7 & 10 & 3 \\
\hline $\mathrm{K}_{7}$ & $0^{*}$ & $\mathbf{I}$ & II & 15 & 3 \\
\hline \multicolumn{6}{|c|}{ Undernutrition group } \\
\hline $\mathrm{U}_{1}$ & o & 3 & $\circ$ & 18 & 4 \\
\hline $\mathrm{U}_{2}$ & q & 2 & 6 & 10 & 14 \\
\hline $\mathrm{U}_{3}$ & q & 3 & $\circ$ & I3 & 15 \\
\hline $\mathrm{U}_{4}$ & $\hat{\sigma}$ & $\mathbf{I}$ & 2 & 6 & 3 \\
\hline $\mathrm{U}_{5}$ & q & 4 & o & 12 & I I \\
\hline $\mathrm{U}_{6}$ & d & 3 & 0 & I3 & 9 \\
\hline
\end{tabular}


kwashiorkor) are noticeably absent, but dryness of the hair and skin and some depigmentation may be evident. Mental and emotional attitudes correspond approximately to those seen in kwashiorkor though irritability is less pronounced. Oedema may be present but is restricted in distribution to the feet and ankles. The liver is usually not palpable and not fatty. Six cases, three males and three females (Table I), with ages ranging from I year and 2 months to 4 years were selected for study in this group.

\section{Diets}

Before admission. In the kwashiorkor group, patients $\mathrm{K}_{1}, \mathrm{~K}_{2}, \mathrm{~K}_{3}, \mathrm{~K}_{4}$ and $\mathrm{K}_{7}$ were reported to have been breast fed for periods varying between 8 months and $I_{2} \frac{1}{2}$ years. Except for $\mathrm{K}_{7}$, who was on a milk diet throughout, they had been weaned on rice diets containing varying amounts of vegetables and pulses with occasional helpings of meat and fish. Malted milk had also been given as a supplement to some patients. The onset of illness occurred at periods varying from 2 to 7 months before admission.

The younger children in the group $\left(\mathrm{K}_{5}, \mathrm{~K}_{6}\right)$ had also been initially breast fed for short periods; supplements of condensed milk had also been given. They had developed signs $2-3$ weeks before admission.

In the undernutrition group, patients $U_{1}, U_{2}, U_{5}$ and $U_{6}$ had been breast fed for periods varying from $I$ to 2 years. $U_{4}$ had been transferred at the age of $2 \frac{1}{2}$ months from breast milk to dried full-cream milk, which he received till I year old. $\mathrm{U}_{3}$ had been deserted by her mother at the age of 18 months and no dietetic history was available. These children had been weaned at ages between $I$ and 2 years on rice diets consisting mainly of rice with varying amounts of meat, fish and vegetables.

The diets on the whole showed no marked differences in the two groups; a noteworthy point was that two children in the undernutrition group and three in the kwashiorkor group had been given malted milk for appreciable periods before the onset of illness.

After admission. The diet given depended largely on the condition of the patient. A variety of high-protein diets was used as soon as practicable. In the kwashiorkor group $\mathrm{K}_{1}$ and $\mathrm{K}_{4}$ began on skim milk and the ward high-protein $\left(\mathrm{S}_{2}\right)$ diet, which contained about $20 \%$ protein and was usually given to malnourished children in the ward. It included rice ( $4 \mathrm{oz})$, bread $(2 \mathrm{oz})$, pulses $\left(\frac{1}{2} \mathrm{oz}\right)$, vegetables $(3 \mathrm{oz})$, egg $(5 \mathrm{oz})$, meat or fish ( $\mathrm{I} \mathrm{oz}$ ), dried fish ( $\left.\frac{1}{2} \mathrm{oz}\right)$, plantain (4 oz), sugar ( $\left.\mathrm{I} \mathrm{oz}\right)$, fresh milk (6 oz) and lime-juice, coconut, chillies, salt and curry powders in small quantities.

$\mathrm{K}_{3}$ was given skim milk at the beginning and after a few weeks was put on Multipurpose Food (MPF), a preparation of vegetable and milk proteins made by Meals for Millions Foundation Inc., Los Angeles I4, California. The manufacturers state that $2 \mathrm{oz}$ dry weight provide $200 \mathrm{kcal}$ and contain: protein $24 \mathrm{~g}$, calcium $333 \mathrm{mg}$, iron $4 \mathrm{mg}$, phosphorus $250 \mathrm{mg}$, iodine $0.03 \mathrm{mg}$, vitamin A 1667 i.u., thiamine $0.40 \mathrm{mg}$, riboflavin $0.67 \mathrm{mg}$, nicotinamide $4 \mathrm{mg}$, vitamin D I33 i.u.

$\mathrm{K}_{6}$ was given skim milk initially, later changed to Lacidac (Lactic Acid Milk Food, containing 3.5\% lactic acid, Cow and Gate Ltd, Guildford, England).

$\mathrm{K}_{2}, \mathrm{~K}_{5}$ and $\mathrm{K}_{7}$ were fed on Casilan (Glaxo Laboratories Ltd, Greenford, Middlesex, 
stated to contain: protein $90 \%$, fat $\mathrm{r} \cdot 8 \%$, moisture $4 \%$, salts $3.8 \%$, glyceryl monooleate $0.4 \%$, calcium $340 \mathrm{mg} / \mathrm{oz}$ ) and on the ward high-protein $\mathrm{S}_{2}$ diet.

In the undernutrition group, $\mathrm{U}_{1}$ was put on the $\mathrm{S}_{2}$ diet with Casilan. $\mathrm{U}_{2}$ was given skim milk and a full-cream milk initially but, owing to the development of diarrhoea, was transferred for some time to Sempo, a dried half-cream milk containing (approx.): butterfat not less than 14 , protein 32 , lactose 44 , mineral salts 7 , moisture $3 \%$ (The Danish Condensed Milk Factory Ltd, Nakshov, Denmark). When the diarrhoea cleared, the child was put on the $\mathrm{S}_{2}$ diet with Casilan. $\mathrm{U}_{3}$ was put on a skim-milk diet for the 3 weeks she was kept under observation. $\mathrm{U}_{4}$ had Casilan initially, soon changed to half-cream milk and later to skim milk; subsequently a modified $\mathrm{S}_{2}$ diet of mashed eggs, bread and vegetables was given. $U_{5}$ was on MPF, $S_{2}$ and then a skim-milk diet. $\mathrm{U}_{6}$ was on a skim-milk diet for the 3 weeks that he survived after admission.

\section{Symptoms and signs observed}

Oedema. In the kwashiorkor group, all the subjects, except $\mathrm{K}_{7}$ who had no noticeable oedema, exhibited varying degrees of this sign distributed over the hands, feet, face and abdomen. $K_{4}$ was affected only on the hands and feet, and $K_{5}$ and $K_{6}$ only on the face and feet. The duration of the oedema (as stated by the parents) was for periods ranging from to to $2 \mathrm{I}$ days before admission except for $\mathrm{K}_{2}$, in whom it had begun 6 months before admission. Clinically, we do not regard oedema as one of the diagnostic criteria distinguishing kwashiorkor from undernutrition though we concede that it is almost always present in fairly severe degree in the former condition. In the undernutrition group, $U_{1}, U_{3}, U_{5}$ and $U_{6}$ had slight to moderate oedema of the feet; $U_{5}$ had, in addition, slight oedema of the face. $\mathrm{U}_{2}$ and $\mathrm{U}_{4}$ did not show any oedema at all. In general we regard oedema when it does occur in undernutrition as being much less severe and more restricted in distribution than in kwashiorkor.

Skin. In the kwashiorkor group, all except $\mathrm{K}_{1}, \mathrm{~K}_{4}$ and $\mathrm{K}_{7}$ showed pigmentation on the hands and feet described as characteristic or diagnostic of kwashiorkor. The 'crazy pavement' or peeling pellagroid dermatosis or pigmented rash was seen in these cases on the hands and around pressure points such as the buttocks and the posterior aspects of the knees and ankles. $K_{1}$ showed only ulceration of the feet but no pigmented rash and $K_{7}$ showed pigmentation but no rash. $K_{2}$ in addition had also ulceration on the hands and $K_{3}, K_{5}$ and $K_{6}$ had also a rash on the abdomen. $K_{4}$ alone showed no skin changes at all. In the undernutrition group, $\mathrm{U}_{1}$ had a dry and lustreless skin and $U_{3}$ a coarse skin on admission. The others had smooth normal skins on admission.

Hair. Dry, pigmented, brittle or 'staring' hair was observed in both groups. All the kwashiorkor patients except $\mathrm{K}_{1}$ showed altered (brown) pigmentation (hypochromotrichia), $K_{5}$ showed only the last and $K_{4}$ and $K_{6}$ showed only dryness and pigmentation. In the undernutrition group, the brown pigmentation was present in all the subjects except $\mathrm{U}_{3}$, who had no hair changes. 'Staring' hair was observed in $\mathrm{U}_{4}$ and $\mathrm{U}_{5}$, dryness in $\mathrm{U}_{1}, \mathrm{U}_{4}$ and $\mathrm{U}_{6}$, and brittleness in $\mathrm{U}_{1}, \mathrm{U}_{2}$ and $\mathrm{U}_{4}$.

Ocular changes. In both groups most of the subjects had xerophthalmia and conjunctival pigmentation. Photophobia was usually present. Most of the children showed 
long broom-like eye-lashes which we have observed to be characteristic of undernutrition. In two, $U_{1}$ and $U_{2}$, circumcorneal vascularization was observed.

Liver. In all the kwashiorkor patients, the liver was enlarged, i.e. palpable two or more finger-breadths below the costal margin, except in $\mathrm{K}_{2}$ in whom it was just palpable. In three patients, liver biopsies were done shortly after admission and showed heavy fatty infiltration. In the undernutrition group, the livers were not palpable, except for $\mathrm{U}_{2}$, in whom it was just palpable. Liver biopsies done on three patients, $\mathrm{U}_{1}, \mathrm{U}_{4}$ and $\mathrm{U}_{5}$, showed no fatty infiltration.

Diarrhoea. In the kwashiorkor group, $\mathrm{K}_{1}, \mathrm{~K}_{2}$ and $\mathrm{K}_{3}$ had histories of diarrhoea reported to have begun from I day to 5 months before admission. $K_{4}, K_{5}$ and $K_{6}$ developed diarrhoea after admission to hospital. $K_{7}$ had no diarrhoea at all. $K_{2}, K_{3}$ and $\mathrm{K}_{4}$ on examination were found to have Ascaris lumbricoides ova in their stools and $\mathrm{K}_{2}$ and $\mathrm{K}_{3}$ those of Trichuris trichiura. They were dewormed with piperazine citrate (Antepar Elixir, Burroughs Wellcome and Co., London). Of the marasmic patients, $\mathrm{U}_{1}, \mathrm{U}_{3}$ and $\mathrm{U}_{4}$ had no diarrhoea on admission; $\mathrm{U}_{2}$ had a history of two attacks, one 3 months and the other 16 days before admission. The stools of all were found to contain ova of Ascaris lumbricoides or Trichuris trichiura and they were all treated with piperazine citrate.

Mental changes. All the subjects showed the lassitude, apathy, and irritability that appears to be characteristic of marasmic conditions. These features were as marked in the undernutrition group as in the kwashiorkor group.

\section{RESULTS}

\section{Effect of treatment on the clinical features observed on admission}

Oedema. The duration of the oedema in the kwashiorkor group ranged from in to 2I days. In the undernutrition group, three patients, $U_{1}, U_{5}$ and $U_{6}$, lost their oedema within 8 days, but in one, $\mathrm{U}_{3}$, it lasted for over 3 weeks. In general the oedema in the undernutrition group was much less severe than in the kwashiorkor group, as was seen from the distribution, extent and time taken for it to disappear.

Skin. The skin condition in the kwashiorkor group gradually improved with the clinical condition (Table 2). The time taken for recovery did not appear to bear any relation to the clearing of the oedema in these subjects. In the undernutrition group the dry skin of $U_{1}$ took 3 weeks, and the coarse skin of $U_{3}$ took 7 weeks to clear.

Hair. No marked changes were observed in either group within to weeks of treatment after admission to hospital.

Eyes. In both groups xerophthalmia cleared up in $3^{-4}$ weeks, photophobia in 2-3 weeks and 'gutter' pigmentation of the conjunctivae in 2-4 weeks; the long eye-lashes remained even after regression of other clinical signs.

Liver. The enlarged livers in the kwashiorkor group were reduced to one fingerbreadth below the costal margin in 2-5 weeks after admission to hospital.

Diarrhoea. $\mathrm{K}_{1}$ and $\mathrm{K}_{3}$ recovered spontaneously within 2 days. $\mathrm{K}_{2}$ recovered in I I days after antibiotic therapy. $\mathrm{K}_{4}, \mathrm{~K}_{5}$ and $\mathrm{K}_{6}$ developed diarrhoea in the ward which, in two of them, $\mathrm{K}_{5}$ and $\mathrm{K}_{6}$, did not clear up for over $\mathrm{I}$ month in spite of antibiotic 
Table 2. Time (days) taken after beginning of treatment for disappearance of oedema, disappearance of skin signs, general improvement in the clinical condition and attainment of normal $\alpha$-globulin values in patients with kwashiorkor or undernutrition

\begin{tabular}{|c|c|c|c|c|}
\hline \multirow[b]{2}{*}{$\begin{array}{l}\text { Patient, } \\
\text { code no. }\end{array}$} & \multicolumn{2}{|c|}{ Disappearance of } & \multirow[b]{2}{*}{$\begin{array}{c}\text { Clinical } \\
\text { improvement }\end{array}$} & \multirow{2}{*}{$\begin{array}{r}\text { Attainme } \\
\text { normal } \alpha-g \\
\text { value }\end{array}$} \\
\hline & Oedema & $\begin{array}{l}\text { Skin } \\
\text { signs }\end{array}$ & & \\
\hline \multicolumn{5}{|c|}{ Kwashiorkor group } \\
\hline $\mathrm{K}_{1}$ & 19 & 10 & IO & 26 \\
\hline $\mathrm{K}_{2}$ & 10 & 21 & $2 I$ & 56 \\
\hline $\mathrm{K}_{3}$ & 21 & 12 & 16 & 27 \\
\hline $\mathrm{K}_{4}$ & 17 & - & I 8 & 12 \\
\hline $\mathrm{K}_{5}$ & 21 & $2 \mathrm{I}$ & 35 & 28 \\
\hline $\mathbf{K}_{6}$ & II & 24 & 28 & 28 \\
\hline$K_{7}$ & 一 & 4 & 28 & 4 \\
\hline \multicolumn{5}{|c|}{ Undernutrition group } \\
\hline $\mathrm{U}_{1}$ & 8 & $2 \mathrm{I}$ & 28 & 6 \\
\hline $\mathrm{U}_{2}$ & - & - & 28 & 25 \\
\hline $\mathrm{U}_{3}$ & I4 & 49 & 70 & $>18$ \\
\hline $\mathrm{U}_{4}$ & - & - & $2 \mathrm{I}$ & 10 \\
\hline $\mathrm{U}_{5}$ & 7 & - & 7 & 24 \\
\hline $\mathrm{U}_{6}$ & 7 & - & No improvement & $>9$ \\
\hline
\end{tabular}

treatment. Of the three patients with diarrhoea in the undernutrition group, two, $\mathrm{U}_{2}$ and $\mathrm{U}_{5}$, responded to antibiotic therapy within 3 weeks; the third, $\mathrm{U}_{6}$, did not respond, and death ensued 3 weeks after admission.

Mental condition. There was a definite improvement in the mental state in four kwashiorkor patients, $K_{1}, K_{2}, K_{3}$ and $K_{7}$, within 16-27 days after admission. $K_{4}$ showed some improvement but after 5 weeks her condition was further complicated by measles contracted in the ward; it should be mentioned, however, that $\mathrm{K}_{1}$ and $\mathrm{K}_{2}$ similarly infected showed improvement. $\mathrm{K}_{5}$ and $\mathrm{K}_{6}$ also showed no improvement though they stayed nearly 5 and I 2 weeks, respectively, under treatment. The fact that these two subjects had unresolved diarrhoea for over a month may have had something to do with it. In the undernutrition group, recovery appeared to be somewhat slower; on an average it took 30 days ( $17-37$ days for five patients) for a patient to show marked mental and emotional improvement as against 2I days ( $16-27$ days for four patients) in kwashiorkor.

Clinical improvement. The time taken for overall clinical improvement in both groups was approximately the same, the period varying from to to 35 days.

\section{Total plasma proteins and albumin:globulin ratio}

The results for total plasma proteins and of the electrophoretic analyses are given in Tables 3 and 4 . Wunderly (1954) has reported on the distribution of the total protein among the individual fractions in human serum as determined by paper electrophoresis. We have taken the mean values quoted by him as our reference values. They are: albumin $6 \mathrm{r} \cdot 6 \%$, $\alpha$-globulin I 1.2\% $\left(\alpha_{1}\right.$-globulin $3.9 \%, \alpha_{2}$-globulin $\left.7.3 \%\right)$, $\beta$-globulin $10.7 \%, \gamma$-globulin $16.5 \%$. As we have used plasma throughout our 
determinations, the values determined for $\gamma$-globulin include fibrinogen. Dean (I955) has reported that his acute cases show a band to the left of the $\gamma$-globulin. We found this band in most of our cases and identify it with fibrinogen. Thompson (1953) obtained a mean value of II.9\% for total $\alpha$-globulin in cases of kwashiorkor after treatment, which is in good agreement with the total of $\alpha_{1}$-globulin and $\alpha_{2}$-globulin $(\mathrm{I} \times 2 \%)$ given by Wunderly. The $\beta$-globulin value obtained by Thompson in the same study is somewhat lower $(7.3 \%)$ and the $\gamma$-globulin value much higher $(26.5 \%)$ than the normal value given by Wunderly. The latter figure is in fair agreement with values for $\gamma$-globulin obtained by us.

Kwashiorkor group. The total plasma proteins of the subjects with a history of a high-carbohydrate, low-protein diet were lower than of those on diets containing milk. However, those who had been given malted milk as a milk food for considerable periods seemed to have lower plasma-protein levels than those fed on other milk foods. The albumin values in all patients were low, as were the albumin:globulin ratios (mean 0.52 ). In most patients, transference to the high-protein diet resulted in rapid improvement in the albumin values within $2-3$ weeks. In those patients who took longer (4-5 weeks), the slower recovery appeared to be due to secondary febrile infections; with the elimination of fever and infection by means of antibiotic therapy, the value of the albumin:globulin ratio usually rose above unity. In all patients, the total-protein values rose to between 6 and $7 \mathrm{~g} / \mathrm{roo} \mathrm{ml}$ with improvement in the clinical condition, provided no diarrhoea or secondary infection was present.

Undernutrition group. The values for total proteins and albumin in these patients tended to differ considerably from one to another and the response to dietary treatment was slow, unlike in the kwashiorkor group. One patient, $\mathrm{U}_{3}$, was diagnosed after 3 weeks to be suffering from pyelonephritis; another, $U_{6}$, died after 3 weeks. Of the others, improvement in $U_{2}$ and $U_{4}$ was faster than in $U_{1}$ and $U_{5}$. In the last two, the slow progress appeared to be due to the occurrence of secondary infections during treatment.

\section{Kwashiorkor group \\ Individual fractions of plasma globulins}

Total $\alpha$-globulins. Of the seven patients studied, $\mathrm{K}_{2}, \mathrm{~K}_{3}, \mathrm{~K}_{5}$ and $\mathrm{K}_{6}$ had very high initial values averaging $30 \%$, which decreased markedly after 2 weeks' treatment to an average of $19 \% ; K_{1}, K_{4}$ and $K_{7}$ had normal values, averaging $15 \%$, and showed no marked variations on treatment. The high values came down to normal within 3-8 weeks of treatment.

$\alpha_{1}$-Globulins. Patients $\mathrm{K}_{1}, \mathrm{~K}_{4}$ and $\mathrm{K}_{7}$ had normal values which decreased on treatment; the others had higher values averaging 10 $\%$, which decreased after 2 weeks to about $5 \%$. The average at the end of several weeks' treatment was about $2-3 \%$.

$\alpha_{2}$-Globulins. Again, patients $\mathrm{K}_{2}, \mathrm{~K}_{3}, \mathrm{~K}_{5}$ and $\mathrm{K}_{6}$ showed considerably increased values averaging $2 \mathrm{I} \%$ and, in all, the values decreased rapidly on treatment to an average of $12 \% . \mathrm{K}_{1}, \mathrm{~K}_{4}$ and $\mathrm{K}_{7}$ had values somewhat higher (10\%) than normal adult values, and on treatment they did not change markedly.

$\beta$-Globulins. There was no clear distinction between patients $\mathrm{K}_{1}, \mathrm{~K}_{4}$ and $\mathrm{K}_{7}$ and the 
Table 3. Components of plasma, determined by electrophoresis on paper, of patients with kwashiorkor, on admission and after 5 weeks' treatment

\begin{tabular}{|c|c|c|}
\hline $\begin{array}{l}\text { Patient, } \\
\text { code no. }\end{array}$ & $\begin{array}{c}\text { Total } \\
\text { protein } \\
(\mathrm{g} / \text { roo } \mathrm{ml})\end{array}$ & $\begin{array}{c}\text { Albumin } \\
(\%)\end{array}$ \\
\hline
\end{tabular}

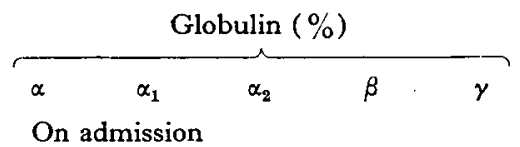

Ratio, albumin:

$\begin{array}{lrr}\mathrm{K}_{1} & 3 \cdot 4 & 3 \mathrm{I} \cdot 2 \\ \mathrm{~K}_{2} & 3 \cdot 8 & 25 \cdot 5 \\ \mathrm{~K}_{3} & 4 \cdot 3 & 3 \mathrm{I} \cdot 3 \\ \mathrm{~K}_{4} & 3 \cdot 8 & 27 \cdot \mathrm{I} \\ \mathrm{K}_{5} & 4 \cdot 4 & 4 \mathrm{I} \cdot \mathrm{I} \\ \mathrm{K}_{8} & 5 \cdot 3 & 32 \cdot 7 \\ \mathrm{~K}_{7} & 6 \cdot 6 & 46 \cdot 4 \\ \text { Mean* } & 4 \cdot 2 & 3 \mathrm{I} \cdot 5 \\ \quad \text { s.D. } & \pm 0 \cdot 7 & \pm 5 \cdot 5\end{array}$

On admission
$6.7 \quad 6.0$

\begin{tabular}{|c|c|c|c|c|}
\hline 16.7 & 10.7 & $5^{\cdot I}$ & $47^{\circ} \circ$ & 0.46 \\
\hline 10.5 & $19 \cdot 1$ & 12.0 & $33 \cdot 0$ & 0.34 \\
\hline II & $20 \cdot 1$ & $14 \% 7$ & $23^{\circ} 0$ & 0.46 \\
\hline $5^{\cdot 8}$ & 10.4 & $8 \cdot \circ$ & $4^{8 \cdot 7}$ & 0.37 \\
\hline 10.8 & $26 \cdot 0$ & 6.5 & $15 \cdot 6$ & 0.70 \\
\hline $6 \cdot 6$ & 217 & $\mathrm{II} \cdot 6$ & $27 \cdot 2$ & 0.49 \\
\hline $4 \cdot I$ & $8 \cdot 8$ & $9 \cdot 6$ & $3 I \cdot I$ & 0.87 \\
\hline $8 \cdot 5$ & $18 \cdot 0$ & $9 \cdot 7$ & 32.4 & 0.47 \\
\hline \pm 2.5 & $\pm 6 \cdot 2$ & \pm 3.7 & \pm 13.0 & 0.12 \\
\hline
\end{tabular}

After treatment

\begin{tabular}{|c|c|c|c|c|c|c|c|c|}
\hline $\mathbf{K}_{1}$ & $5 \cdot 3$ & $39 \cdot 4$ & $15 \cdot I$ & $5 \cdot 3$ & $9 \cdot 9$ & 10.9 & $34 \cdot 6$ & 0.65 \\
\hline $\mathrm{K}_{2}$ & $6 \cdot 1$ & 50.5 & $17 \cdot 1$ & $5^{2}$ & II:9 & 10.4 & $21 \cdot 8$ & 1.02 \\
\hline $\mathrm{K}_{3}$ & $7 \cdot 8$ & $5 \mathrm{I} \cdot 6$ & 14.3 & $4 \cdot \mathrm{I}$ & 10.3 & $I I \cdot I$ & $23 \cdot 2$ & 1.07 \\
\hline $\mathrm{K}_{4}$ & $6 \cdot I$ & $5 I \cdot 2$ & $9 \circ 0$ & $I \cdot 8$ & $7 \cdot 2$ & $13^{\cdot 8}$ & $26 \cdot 8$ & 1.05 \\
\hline $\mathrm{K}_{5}$ & 6.6 & $56 \cdot 7$ & 14.3 & $I .7$ & $12 \cdot 6$ & $10 \cdot 7$ & 18.3 & I. $3 \mathrm{I}$ \\
\hline $\mathrm{K}_{6}$ & $5 \cdot 6$ & $47 \cdot 7$ & $12 \cdot 9$ & $2 \cdot 2$ & 10.7 & $13 \cdot 1$ & $26 \cdot 3$ & 0.91 \\
\hline $\mathrm{K}_{7}$ & 6.6 & 40.8 & $12 \cdot 1$ & $2 \cdot 7$ & $9 \cdot 3$ & $9 \cdot 7$ & $37 \cdot 2$ & 0.69 \\
\hline Mean* & $6 \cdot 3$ & 49.5 & 1 3.8 & $3 \cdot 4$ & $10 \% 4$ & $11 \cdot 7$ & $25 \cdot 2$ & 0.98 \\
\hline S.D. & \pm 0.9 & \pm 5.7 & $\pm 2 \cdot 7$ & $\pm 1 \cdot 7$ & $\pm r \cdot 9$ & $\pm r^{\prime} \cdot 4$ & $\pm 5 \cdot 6$ & \pm 0.22 \\
\hline \multicolumn{9}{|l|}{ Serum } \\
\hline \multirow{2}{*}{\multicolumn{2}{|c|}{$\begin{array}{l}\text { (Thompson, 1953) 7•3 } \\
\text { (Wunderly, 1954) - }\end{array}$}} & $52 \cdot 6$ & II $\cdot 9$ & - & $\bar{n}$ & 8.9 & $26 \cdot 5$ & $1 \cdot 17$ \\
\hline & & $6 \mathrm{I} \cdot 6$ & $I I \cdot 2$ & $3 \cdot 9$ & $7 \cdot 3$ & 10.7 & 16.5 & 1.60 \\
\hline
\end{tabular}

* Values for $\mathrm{K}_{7}$ have not been used in the calculation as this patient was subsequently shown not to be suffering from kwashiorkor (see p. 497).

Table 4. Components of plasma, determined by electrophoresis on paper, of patients with undernutrition, on admission and after 5 weeks' treatment

\begin{tabular}{|c|c|c|c|c|c|c|c|c|}
\hline \multirow[b]{2}{*}{$\begin{array}{l}\text { Patient, } \\
\text { code no. }\end{array}$} & \multirow{2}{*}{$\begin{array}{c}\text { Total } \\
\text { protein } \\
(\mathrm{g} / \mathrm{r} \text { / } \mathrm{ml})\end{array}$} & \multirow[b]{2}{*}{$\begin{array}{c}\text { Albumin } \\
(\%)\end{array}$} & \multicolumn{5}{|c|}{ Globulin $(\%)$} & \multirow{2}{*}{$\begin{array}{l}\text { Ratio, } \\
\text { albumin } \\
\text { globulin }\end{array}$} \\
\hline & & & $\alpha$ & $\alpha_{1}$ & $\alpha_{2}$ & $\beta$ & $\gamma$ & \\
\hline \multicolumn{9}{|c|}{ On admission } \\
\hline$U_{1}$ & $2 \cdot 4$ & $39 \cdot 5$ & II $\cdot 4$ & $5 \cdot 8$ & $5 \cdot 6$ & $14 \cdot 9$ & $34 \cdot 2$ & 0.65 \\
\hline$U_{2}^{2}$ & $4 \cdot 0$ & 35.4 & $28 \cdot 4$ & $9 \cdot 2$ & $20 \cdot 0$ & $9 \cdot 6$ & $25 \cdot 7$ & 0.55 \\
\hline $\mathrm{U}_{3}$ & 3.4 & 32.9 & $18 \cdot 3$ & $8 \cdot 0$ & $10 \cdot 3$ & $8 \cdot 1$ & $4 r^{\circ} \cdot 4$ & 0.49 \\
\hline $\mathrm{U}_{4}^{\circ}$ & $5 \cdot 8$ & $44 \cdot 7$ & 18.9 & $3 \cdot 9$ & 14.9 & $8 \cdot 3$ & $28 \cdot 4$ & $0.8 I$ \\
\hline $\mathrm{U}_{\mathrm{s}}$ & $3 \cdot 9$ & $20 \cdot \mathrm{I}$ & $23 \cdot 6$ & $5 \cdot 4$ & $18 \cdot 2$ & $7 \cdot 9$ & $48 \cdot 0$ & 0.25 \\
\hline$U_{6}$ & $4 \cdot 7$ & $28 \cdot 8$ & $22 \cdot 5$ & $9 \cdot 4$ & 13.8 & $6 \cdot 2$ & $42 \cdot 6$ & 0.40 \\
\hline Mean & $4: 0$ & $33 \cdot 6$ & 20.5 & 6.9 & $13 \cdot 8$ & $9 \cdot 2$ & $36 \cdot 7$ & 0.53 \\
\hline S.D. & $\pm 1 \cdot 2$ & $\pm 2 \cdot 7$ & \pm 5.8 & $\pm 2 \cdot 2$ & $\pm 5 \cdot 1$ & $\pm 3 \cdot 0$ & \pm 8.7 & \pm 0.25 \\
\hline \multicolumn{9}{|c|}{ After treatment } \\
\hline $\mathrm{U}_{\mathrm{i}}$ & $5 \cdot 4$ & $5 \mathrm{I} \cdot 0$ & $19 \cdot 7$ & $5 \cdot 4$ & 14.3 & $7 \cdot 8$ & $21 \cdot 7$ & $1 \cdot 04$ \\
\hline $\mathrm{U}_{2}$ & 5.6 & $44^{\circ} 4$ & 13.6 & 3.5 & $10 \cdot I$ & I $2 \cdot I$ & $29^{\circ} 9$ & 0.80 \\
\hline $\mathrm{U}_{3}{ }^{*}$ & $7 \cdot 7$ & $30 \cdot 0$ & 20.6 & 7.8 & $12 \cdot 8$ & 16.9 & $32 \cdot 5$ & 0.43 \\
\hline & 5.9 & $49^{\circ} \circ$ & $17 \cdot 0$ & $4 \cdot 2$ & I $2 \cdot 8$ & $12 \cdot 7$ & $2 I \cdot 3$ & 0.96 \\
\hline $\mathrm{U}_{5}^{*}$ & 6.0 & $30 \cdot 1$ & 15.5 & 3.5 & II 8 & 8.0 & $46 \cdot 6$ & 0.43 \\
\hline $\mathrm{U}_{6}{ }^{*}$ & $6 \cdot 4$ & $37 \cdot 6$ & $17 \cdot \mathrm{I}$ & 5.8 & $I I \cdot 2$ & $7 \cdot 6$ & $37 \cdot 7$ & 0.60 \\
\hline Mean & $6 \cdot 2$ & $40 \cdot 4$ & $17 \cdot 2$ & $5 \cdot 0$ & $12 \cdot 2$ & 10.9 & $31 \cdot 5$ & $0.7 \mathrm{I}$ \\
\hline s.D. & \pm 0.8 & $\pm 9 \cdot I$ & $\pm 2 \cdot 6$ & $\pm I \cdot 7$ & $\pm r \cdot 5$ & $\pm 3 \cdot 7$ & \pm 9.7 & \pm 0.27 \\
\hline
\end{tabular}

* Values after 3 weeks' treatment (see p. 488 ). 
others except that their mean initial value was lower. In all, the initial values lay between 5 and $15 \%$ and altered during treatment to a final value of about $10 \%$.

$\gamma$-Globulins (including fibrinogen). The values obtained varied from child to child. $\mathrm{K}_{1}, \mathrm{~K}_{4}$ and $\mathrm{K}_{7}$ had initial values two to three times the normal adult ones. During 3 weeks of treatment, the value decreased somewhat in two patients and increased in one. In one, $\mathrm{K}_{5}$, the value was normal and, except for a temporary increase, remained normal during 6 weeks of treatment. In $K_{3}$ and $K_{6}$ the value was high at the beginning and did not change during treatment. In one, $\mathrm{K}_{2}$, the initial high value decreased to near normal. In view of these variations we are inclined to believe that values for $\gamma$-globulin are of no special diagnostic value in kwashiorkor.

\section{Undernutrition group}

Total $\alpha$-globulins. Except for $U_{1}$, the values were high on admission and fell after 4-5 weeks to about $15 \%$. In $U_{1}$ the value rose on treatment from a normal initial value to $20 \%$.

$\alpha_{1}$-Globulins. Except for $\mathrm{U}_{2}, \mathrm{U}_{3}$ and $\mathrm{U}_{6}$, in whom the values were initially high ( $9 \%$ ), the values were normal and after undergoing small irregular variations came down to about $3 \%$ after Io weeks of treatment. In $\mathrm{U}_{2}$ the value likewise decreased to about $2 \%$ after ro weeks.

$\alpha_{2}$-Globulins. All the values except in $\mathrm{U}_{1}$ were initially lower than normal, undergoing small up-and-down variations during treatment and ultimately (after 10 weeks) decreasing to about $10 \%$.

$\beta$-Globulins. All the values, except in $\mathrm{U}_{1}(14.9 \%)$, were initially lower than normal. A final value of about $9 \%$ was reached after io weeks of treatment.

$\gamma$-Globulins (including fibrinogen). In all patients, the initial values were high (one and a half to three times the normal adult value) and decreased slightly on treatment.

\section{DISCUSSION}

In the kwashiorkor group, the chief diagnostic feature common to most patients was the extensive and severe nature of the oedema and skin lesions, usually accompanied by an enlarged, fatty liver and diarrhoea. Hair and eye signs were usually found, as in the undernutrition group. Waterlow, Bras \& De Pass (1957) state that they look upon oedema as a feature distinguishing kwashiorkor from marasmus. Our observations indicate that it can be regarded as distinguishing only when it is extensive in distribution and fairly severe in extent. The plasma-protein figures revealed low albumin: globulin ratios, as in the undernutrition group at the beginning of treatment. The most striking deviation from normal values occurred in the relative amounts of the $\alpha$ globulin fractions.

The $\alpha$-globulin values usually declined to the normal range (I I-I $2 \%$ ) only after prolonged treatment. If a marked fall from a high level to about $15 \%$ is taken as an index of improvement in the condition, a fair degree of correlation becomes apparent, except for $\mathrm{K}_{4}$ and $\mathrm{K}_{7}$, between the time taken for the oedema and skin signs to clear, the time taken for clinical improvement and the time taken for $\alpha$-globulin values (see 
Table 2) to become nearly normal. In the light of the biochemical findings, we reviewed the clinical features of $\mathrm{K}_{4}$ and $\mathrm{K}_{7} . \mathrm{K}_{7}$, as seen from Table 2 and further observations made during the course of treatment, appeared to have been incorrectly placed in the kwashiorkor group. He presented none of the usual combinations of signs characteristic of the others. $\mathrm{K}_{4}$ as well as $\mathrm{K}_{1}$ had some but not all the clinical signs shown by this group. For instance, oedema was present but skin lesions were absent and hair changes were not marked. The liver was palpable in these two patients, and in $\mathrm{K}_{4}$ it was infiltrated with fat, as established by biopsy. We are therefore inclined to regard $\mathrm{K}_{4}$ and $\mathrm{K}_{1}$ as in an early stage of the condition, not having manifested the marked relative increase in the $\alpha$-globulin fractions at the time of admission. When the patients judged by both biochemical and clinical findings to be suffering from kwashiorkor $\left(\mathrm{K}_{2}, \mathrm{~K}_{3}, \mathrm{~K}_{5}\right.$ and $\left.\mathrm{K}_{6}\right)$ are considered, the mean values before and after treatment were:

\begin{tabular}{|c|c|c|c|c|c|c|c|c|}
\hline & & & & & obulin & & & Ratio, \\
\hline & $(\mathrm{g} / \mathrm{I} 00 \mathrm{ml})$ & $(\%)$ & $\alpha$ & $\alpha_{1}$ & $\alpha_{2}$ & $\beta$ & $\gamma$ & globulin \\
\hline Before treatment & 4.5 & $32 \cdot 6$ & $3 x \cdot 5$ & 9.7 & $21 \times 7$ & II' 2 & $24 \cdot 7$ & 0.50 \\
\hline S.D. & $\pm I \cdot 0$ & $\pm 6 \cdot 5$ & \pm 43 & $\pm 2 \cdot 2$ & $\pm 2 \cdot 6$ & $\pm 3 \cdot 4$ & $\pm 7 \cdot 3$ & \pm 0.15 \\
\hline After treatment & $6 \cdot 2$ & $5 I \cdot 6$ & 147 & $3 \cdot 3$ & II 4 & II 3 & $22 \cdot 4$ & $\mathbf{I} \cdot 08$ \\
\hline s.D. & $\pm I \cdot 5$ & \pm 3.7 & $\pm \mathbf{r} \cdot 8$ & $\pm x \cdot 6$ & $\pm I \cdot 0$ & $\pm I \cdot 3$ & $\pm I \cdot 7$ & \pm 0.17 \\
\hline
\end{tabular}

A marked fall can be seen in the relative amounts of the $\alpha$ - (both $\alpha_{1}$ - and $\alpha_{2}$-) globulins whereas the $\beta$ - and $\gamma$-globulins underwent little change. Senecal (1955) has stated that, in malnourished children in French West Africa, there was always hypoproteinaemia with a rise in the levels of $\alpha-$ and $\gamma$-globulins. Autret (1955), reporting on work done in Tunisia by Caruana, Hamza \& Ghileb (1953), stated that in patients with oedema, $\alpha_{1}$ - and $\alpha_{2}$-globulins and, to a lesser extent, $\gamma$-globulins are increased.

It is not clear in the references to the work quoted above whether the increases in the amounts of the various globulin fractions refer to relative or absolute increases. Since the total plasma proteins rise during treatment, it is evident that relative increases do not necessarily reflect absolute increases in the individual fractions. Thus, for example, an initial value of $25 \% \alpha$-globulin in $4^{\circ} 00 \mathrm{~g}$ of total protein would represent the same concentration as a final value of $15 \% \alpha$-globulin in $6.67 \mathrm{~g}$ of total protein, namely $\mathrm{I} \cdot 00 \mathrm{~g} \alpha$-globulin. Thus, though the absolute amount of the fraction did not change in this example, its proportion of the total protein decreased. Again, if the bulk of the increase in total protein represents an increase in albumin, the relative amounts of the globulin fractions will decrease though their absolute amounts will remain unchanged. If the increase in total protein is due mainly to haemoconcentration following on diuresis, then all fractions should be equally affected; if on the other hand it is found that with an increase in total protein there is a decrease in the absolute values of certain fractions, then it could be indicative of a pathological process unconnected with purely stoichiometric effects. It is necessary therefore in drawing conclusions to consider the significance of both relative and absolute changes in the amounts of the plasma proteins.

Close (1953) in an electrophoretic study of serum proteins in kwashiorkor patients in the Belgian Congo found an increase in the relative amount of $\alpha$-globulins to a value 
of $20-30 \%$, the values decreasing on treatment, which agrees with our findings; the values after treatment, quoted for three patients only, show that the absolute amounts of $\alpha$-globulins were not affected but that those of the $\beta$ - and $\gamma$-globulins increased. Autret \& Behar (1954) reporting on work carried out in Guatemala quote figures which, compared with normal values, 'show a very definite relative increase of $\alpha$ globulins, chiefly $\alpha_{2}$, and $\gamma$-globulins while the proportion of $\beta$-globulins remains unchanged'. In this work, we find that the absolute values of the $\alpha$-globulins before treatment were normal and those of the $\beta$-globulins decreased, though the authors do not draw attention to this fact in reaching their conclusion; no values are given for these patients after treatment.

Table 5. Mean values $(g / 100 \mathrm{ml})$ for total proteins and individual protein fractions in plasma of patients with kwashiorkor or undernutrition before and after treatment

\begin{tabular}{|c|c|c|c|c|c|c|c|}
\hline \multirow{2}{*}{ Kwashiorkor $\left(\mathrm{K}_{1-\beta}\right)$} & \multirow[b]{2}{*}{$\begin{array}{c}\text { Total } \\
\text { proteins }\end{array}$} & \multirow[b]{2}{*}{ Albumin } & \multicolumn{5}{|c|}{ Globulin } \\
\hline & & & $\alpha$ & $\alpha_{1}$ & $\alpha_{2}$ & $\beta$ & $\gamma$ \\
\hline Before treatment & $4 \cdot 2$ & $I \cdot 33$ & $I \cdot 26$ & 0.35 & 0.77 & $0.4 \mathrm{I}$ & $1 \cdot 30$ \\
\hline S.D. & \pm 0.7 & \pm 0.38 & \pm 0.47 & \pm 0.12 & \pm 0.34 & \pm 0.19 & \pm 0.42 \\
\hline After treatment & $6 \cdot 3$ & $3 \cdot 12$ & 0.86 & 0.21 & 0.65 & 0.73 & $\mathrm{I} \cdot 55$ \\
\hline $\begin{array}{l}\text { S.D. } \\
\text { Kwashiorkor }\left(K_{2,3,5,6}\right)\end{array}$ & \pm 0.8 & \pm 0.70 & \pm 0.19 & \pm 0.10 & \pm 0.14 & \pm 0.12 & \pm 0.26 \\
\hline $\begin{array}{l}\text { Before treatment } \\
\text { S.D. }\end{array}$ & $\begin{array}{r}4.5 \\
+1.0\end{array}$ & $\begin{array}{r}1 \cdot 47 \\
+0.38\end{array}$ & $\begin{array}{r}I \cdot 4 I \\
\pm 0.22\end{array}$ & $\begin{array}{r}0.44 \\
\pm 0.06\end{array}$ & $\begin{array}{r}0.97 \\
+0.21\end{array}$ & $\begin{array}{r}0.51 \\
\pm 0.16\end{array}$ & $\begin{array}{r}r \cdot 11 \\
\pm 0 \cdot 32\end{array}$ \\
\hline After treatment & $6 \cdot 2$ & $3 \cdot 20$ & 0.91 & 0.20 & 0.71 & 0.70 & I. 39 \\
\hline $\begin{array}{l}\text { S.D. } \\
\text { Undernutrition }\left(\mathrm{U}_{1-6}\right)\end{array}$ & $\pm I \cdot 5$ & \pm 0.65 & \pm 0.18 & \pm 0.12 & $\pm 0 \cdot I_{I}$ & $\pm 0 \cdot 1 \mathrm{I}$ & \pm 0.27 \\
\hline Before treatment & $4 \cdot 0$ & $\mathbf{I} \cdot 34$ & 0.82 & 0.28 & 0.55 & 0.37 & $I \cdot 46$ \\
\hline $\begin{array}{l}\text { S.D. } \\
\text { After treatment }\end{array}$ & $\begin{array}{r} \pm I \cdot 2 \\
6 \cdot 2\end{array}$ & $\begin{array}{r} \pm 0.66 \\
2.50\end{array}$ & $\begin{array}{r} \pm 0.34 \\
1.06\end{array}$ & $\begin{array}{r} \pm 0.1 \mathrm{I} \\
0.3 \mathrm{I}\end{array}$ & $\begin{array}{r} \pm 0.28 \\
0.76\end{array}$ & $\begin{array}{r} \pm 0.08 \\
0.68\end{array}$ & $\begin{array}{r} \pm 0.47 \\
I \cdot 95\end{array}$ \\
\hline S.D. & \pm 0.8 & \pm 0.39 & \pm 0.25 & \pm 0.15 & \pm 0.14 & \pm 0.33 & \pm 0.58 \\
\hline Serum (Thompson, 1953) & $7 \cdot 3$ & $3 \cdot 84$ & 0.87 & - & - & 0.65 & $I \cdot 93$ \\
\hline
\end{tabular}

When our figures are recalculated in terms of absolute amounts of each fraction, the mean values show (Table 5 ) that in both groups of patients there was after treatment a large increase in total proteins and albumin, with smaller increases in $\beta$ - and $\gamma$ globulins. The only difference in the two groups is shown in the $\alpha$-globulins which decreased in kwashiorkor but increased in undernutrition. The decrease in the $\alpha$ globulin value in kwashiorkor is more convincing when only the patients $\left(\mathrm{K}_{2}, \mathrm{~K}_{3}, \mathrm{~K}_{5}\right.$, $\mathrm{K}_{6}$ ) in whom the syndrome was well established are considered. The significance of the figures is, however, questionable owing to the small number of patients. It must be conceded that the major change in these patients when placed on high-protein regimes was the restoration of normal albumin levels and that rapid increase in the absolute amount of albumin could bring about fortuitous changes in the relative proportions of the globulin fractions. However, the values in Table 5 show that in the kwashiorkor group the absolute $\alpha$-globulin content was almost equal to the entire albumin content of the plasma, though it was not so in the undernutrition group. Also, the absolute $\alpha$-globulin value tended to decrease in the kwashiorkor group on treatment when increasing total plasma protein and disappearing oedema might well be expected to 
favour an increase in $\alpha$-globulins. This situation inclines us to the view that the relative increase in the values for the $\alpha$-globulins (both $\alpha_{1}$ and $\alpha_{2}$ ) in our kwashiorkor patients, though it does not indicate a distinctive lesion, has diagnostic value when accompanied by the characteristic clinical signs: (I) oedema, extensive and severe; (2) a moderately or a severely fatty liver at biopsy; (3) skin lesions of the peeling pellagroid type, which are frequent in occurrence but not an essential part of the basic syndrome.

It might also be pointed out that, though the relative values for $\gamma$-globulins did not differ appreciably in the two groups, the absolute values in the kwashiorkor group were lower than in the undernutrition group and did not show as big an increase on treatment. The observation made by other workers that kwashiorkor patients have high $\gamma$-globulin values appears in our patients to be correct only when it refers to the relative value for this fraction.

In the clinically diagnosed cases of undernutrition, no significant features emerged from the electrophoretic analysis except the low albumin:globulin ratios at the time of admission; values for the various plasma-protein fractions tended to vary markedly from patient to patient and improvement on high-protein diets was variable. Clinical recovery was generally slow. Oedema when present was not marked; skin signs were usually absent; livers were usually not palpable and not fatty; diarrhoea was not an invariable accompaniment and when present was controllable by antibiotic therapy; hair and eye signs were usually found. No relation was apparent between the time taken to clear these signs, and the time for clinical recovery and a marked fall in the relative value for $\alpha$-globulin, as was observed in kwashiorkor. As far as the biochemical findings were concerned, no results were obtained that conflicted with the correctness of the clinical diagnosis of these cases as being of marasmic undernutrition unconnected with kwashiorkor.

\section{SUMMARY}

I. Two groups of Ceylonese children, one of seven clinically diagnosed as suffering from kwashiorkor (protein malnutrition) and the other of six diagnosed as suffering from undernutrition (marasmus), were placed on high-protein diets, and their blood plasma was examined electrophoretically at weekly intervals.

2. Characteristic signs observed in the kwashiorkor group were severe and extensive oedema, enlarged liver with fatty infiltration and characteristic skin lesions. Other signs, such as hypochromotrichia, lassitude, apathy and irritability were common to both groups.

3. The time taken for general clinical improvement was the same in both groups, though in the patients with kwashiorkor the mental and emotional condition improved more quickly.

4. Both groups showed on the high-protein diets a rapid increase of plasma albumin and total plasma proteins, but the increase in the albumin value in the undernutrition group was quantitatively less.

5. No marked differences were found between the two groups in both relative and absolute values for $\beta$ - and $\gamma$-globulins in the plasma. The relative and absolute values 
for the $\alpha$-globulins were on the average higher in the kwashiorkor group than in the undernutrition group; on treatment, the values tended to fall in the kwashiorkor group but rise in the undernutrition group.

6. The significance of these results is briefly discussed.

\section{REFERENCES}

Autret, M. (1955). In Protein Malnutrition: Proceedings of a Conference in Ұ̈amaica, 1953, p. 59. [J. C. Waterlow, editor.] Rome: FAO/WHO/Josiah Macy Jr. Foundation.

Autret, M. \& Behar, M. (1954). F.A.O. nutr. Stud. no. I3, p. 74.

Brock, J. F. \& Autret, M. (1952). F.A.O. nutr. Stud. no. 8.

Caruana, N., Hamza, B. \& Ghileb, H. (1953). Tunis méd. 41, $26_{5}$.

Close, J. (1953). Ann. Soc. belge Méd. trop. 33, I85.

Dean, R. F. A. (1955). In Protein Malnutrition: Proceedings of a Conference in Famaica, 1953, p. 58. [J. C. Waterlow, editor.] Rome: FAO/WHO/Josiah Macy Jr. Foundation.

Dean, R. F. A. \& Schwartz, R. (1953). Brit. F. Nutr. 7, г 3 I.

Gómez, F., Ramos-Galván, R., Cravioto, J., Frenk, S., De La Peña, C., Moreno, M. E. \& Villa, M.E. (1957). Brit. F. Nutr. Ix, 229.

Gopalan, C. (1955-6). F. trop. Pediat. 1, 206.

Grassmann, W. (I95 I). Naturwissenschaften, 38, 200.

King, E. J. (195 I). Micro-analysis in Medical Biochemistry, 2nd. ed., p. 46. London: J. and A. Churchill.

Mukherjee, K. L. \& Jeliffe, D. B. (1955-6). F. trop. Pediat. r, 6r.

Netrasiri, A. \& Netrasiri, C. (1955-6). F. trop. Pediat. I, I48.

Politzer, W. M. \& Wayburne, S. (1957). Brit. F. Nutr. r1, 105.

Scrimshaw, N. S., Behar, M., Arroyave, G., Viteri, F. \& Tejada, C. (1956). Fed. Proc. I5, 977.

Senecal, J. (1955). In Protein Malnutrition: Proceedings of a Conference in famaica, 1953, p. 57. [J. C. Waterlow, editor.] Rome: FAO/WHO/Josiah Macy Jr. Foundation.

Suckling, P. V. \& Campbell, J. A. H. (1957). F. trop. Pediat. 2, 173.

Thompson, M. D. (1953). Personal communication quoted by Trowell, H. C., Davies, J. N. P. \& Dean, R. F. A. (1954) in Kwashiorkor, p. 213. London: E. Arnold Publishers Ltd.

Waterlow, J., Bras, G. R. \& De Pass, E. (1957). F. trop. Pediat. 2, I9I.

Waterlow, J. \& Vergara, A. (1956). F.A.O. nutr. Stud. no. I4.

Wunderly, Ch. (I954). Die Papierelektrophorese, p. 54. Aarau und Frankfurt am Main: Verlag H. R. Sauerländer and Co. 